\title{
Ancient Rome and Icelandic Culture - A Brief Overview
}

\author{
by Federico Actite
}

The knowledge of Iceland in the Roman world is tied exclusively to a Greek book, On the Ocean, by Greek explorer Pytheas (ca. 380-310 BC.), who spoke of a remote "last Thule" in the far north. Apart from this remark, Iceland remained to the ancient Romans a far-off place, of no strategic or mercantile importance, surrounded by legends and by the dense fog of the Ocean.

On the other hand, even after the fall of the Roman empire, the Romans' language, i.e. Latin, continued to play a very important role in Europe, chiefly because of the process of Christianization of the Continent by the Church of Rome, which exported Latin, together with the new faith, in the north of Europe as well.

Indeed, it would be plausible to suppose that some of the settlers that colonized Iceland might have had some knowledge of the Latin tongue, although no such documental evidence has been found to date. Nevertheless, it is certain that Iceland imported this language during the Middle Ages, after its chieftains' conversion to the Christian creed around the year 1000

Additionally, it should be highlighted that the path by which Latin could reach Iceland was not only the one stemming from Scandinavia. The Viking settlers of Iceland brought with them captives from the British Islands, which had been extensively Romanized. Similarly, the settlers' descendants had frequent commercial and cultural exchanges with the north of Germany, which had already been Christianized in the early Middle Ages.

After the nation's conversion to Christianity, Iceland remained a rural country without significant urban centers. This rural, medieval Iceland had two dioceses, one in the south and one in the north, and few monasteries that, thanks to the foundation of schools annexed to the main churches, became the most important cultural hubs in the country. As a result, the educated class was formed therein, where it acquired some knowledge of classical masterpieces and of Latin qua international language of communication. In particular, the end of the 11th century witnessed a true renaissance for culture in most of Europe, due to the rediscovery of classical authors, who became a standard model for good poetry and literature in general.

The first notice that we have about the knowledge of Roman authors by Icelanders dates back to the time of Jón Ögmundsson (1052-1121), the first bishop in the diocese of the north, Hólar. It is said that he forbade the reading of Ovid's books after he realized that a young priest had been taken in by Ovid's praises of sexual love and his strategies to successfully seduce women. There exist several versions of this tale and the actual events are therefore uncertain. However, they attest the presence and the 
knowledge of Ovid in Iceland during the 11th century.

The first explicit citation of Ovid appears during the 13th century, when Óláfr Pórðarson (ca. 1212-1259), in his third grammatical treatise, makes use of a verse from the Ars Amandi [The art of Love]. In the same years, calendars called rim or rímtöl were very popular, and one of them contains a verse from Ovid's Fasti [The Festivals] explaining the sign of the zodiac Aries. In this text, the unknown author displays a good command of Latin, since he is careful and correct in declining the Latin terms he and applying them to a different context.

In the following century, the Trójumanna saga [The history of the Trojans] is composed, which reveals that at least some Icelanders had read Virgil. Also, in a book called Alexander's Saga there is a citation from the Metamorphoses by Ovid and the author refers to a source called "Ovidius Magnus".

In 1525 Jón Arason (1485-1550), the last Catholic bishop of Hólar, releases his Sigurðarrestigur, an inventory of the books collected by the bishopric which mentions the book Ovideus, De arte amandi. In the same years, after the conversion to Lutheranism, the changes in the curriculum of the schools lead to the study of classical Greek, which in turn increases the study of the ancient Roman world. During this time, Iceland is to produce some humanists enjoying an international reputation, the most important of whom is certainly Arngrìmur Jónsson (1568-1648), who wrote his works in Latin, and the poet Stefán Ólafsson (1619-88), who translated the works of Horace and Cicero and composed new ones inspired by them. However, it is only in the 19th century that the first printed versions of his Icelandic translations are published.

Also in the most popular kind of poetry in Iceland, the rímur, composed by men of all social classes, the names of Latin authors occur several times. For example, a Vergiless rímur written according to the medieval tradition, was composed around the 17th century, in which Virgil is the protagonist of a love-story with a princess. In this composition, the reminiscence of Ovid's Ars Amandi is strong and scholars regard it as an indication of an established literary convention.

This type of poetry was very popular because the subjects treated by them could vary significantly, especially following the influence of $15^{\text {th- }}$ and 16th- century humanism. Still in the 17th century, the poet Stefán Ólafsson wrote a bucolic poem along the lines of Virgil's Georgicae [Georgics] and Guðmundur Andrésson (1615-1654) composed Persius rimur based upon the story of Perseus in the 4 th and $5^{\text {th }}$ books of the Metamorphoses by Ovid.

In the 19th century, Jón Jónsson (1759-1846) composed the Rimur af Aeneasi sterka [Rime of Aeneas' strength], thus translating the first book of Virgil's Aeneis [i.e. Aeneid] into Icelandic verses. Jón Espólín (1769-1836), sheriff in northern Iceland, translated the Metamorphoses into Icelandic in a meter called fornyroislag [Alliterative verse]. In those years many Icelanders, especially common people, tried 
to write rímur inspired by classical authors, e.g. Sigurður Bjarnason (1841-1865), a farmer's son who, at the age of 17, composed a rima of 100 stanzas on the story of Pyramus and Thisbe. Today, his original manuscript is preserved at the National Library of Iceland.

These are only some examples of the great diffusion of Latin culture amongst the Icelanders in the past. It should be added that the influence of Latin was so strong that it was not limited just to literature, for we can find its mark in the Icelandic language, despite the careful cleansing of foreign terms in the Romantic age.

Certainly, Latin influenced most powerfully the jargon of ecclesiastic scholars, but somehow some words reached also the language of common people. For instance, the Latin phrase Rustycus es, Corydon gave origin to the Icelandic words rusti [farmer] and dóni [rude people].

\section{Bibliography}

Sigurður Pétursson: "Islanda" in Enciclopedia Oraziana vol. 3, p. 569, Roma, 1998

Sigurður Pétursson: “Ovid in Iceland” in Pietro Janni, Diego Poli, \& Carlo Santini (eds.), Cultura Classica e Cultura Germanica Settentrionale, pp. 53-63, Roma, 1988

Sigurdur Pétursson: "Islanda" in Enciclopedia Virgiliana, pp. 28-9, Roma, 1987

Rudolf Portner: L'epopea dei Vichinghi, pp. 343-345, Cles (TN), 1972

Federico Actite (b. 1986) is reading Contemporary History at the University of Genoa, Italy, and has spent a semester at the University of Iceland to study Icelandic history. He is writing his undergraduate thesis on the international warship trade by Ansaldo during the Bombrini administration (1883-1903). 